УДК:634.8:581.167:631.532

О. М. Карастан, науковий співробітник, Національний науковий центр «Інститут виноградарства і виноробства ім. В. С. Таїрова» вул. 40-річчя Перемоги, 27, смт Таїрове, Овідіопольський р-н, Одеська обл., 65496, Україна, e-mail: olga.karastan@gmail.com

\title{
РЕКОНСТРУКЦІЯ ГЕНОТИПІВ ТА АНАЛІЗ ПОХОДЖЕННЯ СОРТІВ ВИНОГРАДУ СЕВЕРНИЙ, ОДЕСЬКИЙ СТІЙКИЙ ТА ДЕКОРАТИВНИЙ
}

Отримано алельні профілі дев'яти мікросателітних локусів (VVS2, VVMD5, VVMD7, VVMD25, VVMD27, VVMD28, VVMD32, ZAG79 та ZAG62) для шести сортів винограду селекції ННЦ «IBiB ім. В. С. Таїрова». Аналіз мікросателітних характеристик сортів-нащадків використаний для реконструкції генотипів батьківських сортів Сєвєрний, Одеський стійкий та Декоративний. Підтверджено стосунки «нащадок-батьківський сорт» для сортів Одеський стійкий-Бабяска негре та Декоративний-Сєвєрний.

Ключові слова: генотип, алель, мікросателітний аналіз, виноград, $V$. vinifera $L$.

Ефективність процесу гібридизації в програмах селекції винограду залежить від ступеню «різноякісності» батьківських форм. На фенотиповому рівні різноякісність виражається у контрастності ознак, за якими ведеться добір. На рівні спадкового матеріалу вона проявляється в гетерозиготності локусів, що відповідають за прояв ознак.

Залежність фенотипового прояву ознак від умов навколишнього середовища $[7,10,12]$, а також доступність надійних інструментів аналізу на рівні послідовностей ДНК зумовлюють вибір дослідників на користь молекулярногенетичних методів оцінки батьківських форм.

В останні десятиліття завдяки кодомінантній природі успадкування, значному рівню поліморфізму та відтворюваності результатів, що надає можливість для порівняння результатів між лабораторіями, мікросателітні послідовності або SSR (з англ. Simple Sequences Repeats - послідовності простих повторів) стали найбільш поширеним інструментом для ідентифікації організмів, аналізу походження, ревізій колекцій, популяційно-генетичних досліджень тощо $[7,8,10]$.

Безумовною перевагою використання такого інструменту є одноразове отримання даних в результаті ідентифікації та можливість їх використання на усіх вищезазначених напрямках досліджень.

Ідентифікація батьківських пар за набором мікросателітних маркерів надає можливість оцінити ступінь гетерозиготності їх спадкового матеріалу, визна- 
чити генетичну спорідненість даних сортів та в подальшому підтвердити походження гібридних форм даної комбінації схрещування.

Крім того, дані мікросателітних профілів нащадків дозволяють визначити генотипи батьківських сортів, навіть за умов їх фізичної відсутності у насадженнях.

Метою роботи була ідентифікація генотипів деяких сортів-нащадків за дев'ятьма мікросателітними локусами, відтворення генотипів батьківських сортів Сєвєрний (Северный), Одеський стійкий та Декоративний та аналіз їх походження.

\section{Матеріали та методи досліджень}

Рослинний матеріал, представлений сортами винограду $V$. vinifera $L$. Мускат гамбурзький, Овідіопольський, Огоньок таїровський, Смєна, Ланка та Етюд, був люб'язно наданий відділом селекції, генетики та ампелографії Національного наукового центру «Інститут виноградарства і виноробства ім. В. Є. Таїрова» (далі ННЦ «ІВіВ ім. В. Є. Таїрова»).

Виділення та оцінку якості ДНК, ПЛР за мікросателітними локусами (VVS2, ZAG62, VVMD7, VVMD27, VVMD5, VVMD25, VVMD28, ZAG79, VVMD32) та фрагментний аналіз проводили за методикою, опублікованою в попередніх роботах $[3,4]$. Сорти Каберне, Совіньон та Шардоне були використані як еталонні.

Для реконструювання генотипів та аналізу походження сортів Сєвєрний, Одеський стійкий та Декоративний, мікросателітні профілі сортів Малєнгр ранній $[6,11]$, Фіолетовий ранній [1], Бєрєкє [1], Самал [1], Іллійський [1], Рупестрис дю Ло [6], Бабяска нягре [6], Датьє де Сен Вальє [6] та Сапераві [6] були залучені з відкритих літературних джерел, а генотипи сортів 40 лєт Октября [3], Голубок [3], Іллічівський ранній [3] та Рубін таїровський [4] були виявлені в наших попередніх дослідженнях.

\section{Результати досліджень та їх обговорення}

Сорти Сєвєрний, Одеський стійкий та Декоративний відсутні в ампелографічних колекціях сортів та насадженнях винограду на території материкової України і отримання матеріалу (сорти Сєвєрний та Декоративний) з установиоригінатора (інститут Виноградарства і виноробства ім. Я. І. Потапенка, м. Новочеркаськ, Росія) та ампелографічної колекції сортів Національного інституту винограду і вина «Магарач» наразі неможливе. Таким чином, реконструювання генотипів даних сортів надає змогу отримати алельні характеристики для використання в окремих напрямках дослідження винограду.

Сорт Сєвєрний (синонім Сєвєрний мускат 7) - це столовий, морозостійкий, 3 дуже ранніми строками дозрівання сорт винограду [2]. Виведений у 1936 році, Сєвєрний активно використовувався в процесі створення нових сортів у колишньому СРСР (понад 30 сортів-нащадків) та деяких країнах нині Європейського 
союзу - Чеській республіці (сорт Амос), Угорщині (сорт Галубок) та Німеччині (сорти Гайзенхайм 6493, Гайзенхайм 6493-2, Гайзенхайм 6493-3). За даними Європейського каталогу сортів Vivc [11] Сєвєрний є батьківським сортом для 38 сортів. Слід відмітити, що Vivc наразі є найбільшою, але ще не завершеною базою даних, тому сортів-нащадків Северного може бути значно більше, беручи до уваги той факт, що він входить до складу [11] колекцій наукових установ Австралії, Австрії, Болгарії, Канади, Німеччини, Грузії, Росії та США.

В ННЦ «ІВіВ ім. В. Є. Таїрова» сорт Сєвєрний був залучений до комбінацій схрещування, за результатами яких були отримані сорти Голубок, Іллічівський ранній та Овідіопольський.

Для реконструкції генотипу сорту Сєвєрний були використані алельні характеристики сортів Голубок, Фіолетовий ранній, Бєрєке та Самал (табл. 1). Алельний склад восьми локусів (VVS2, ZAG62, ZAG79, VVMD7, VVMD25, VVMD27, VVMD28 та VVMD32) був відновлений повністю. У локусі VVMD5 всі шість нащадків сорту Сєвєрний (табл. 1, 2) успадкували алель 239 п. о., тому цілком ймовірно, що він є гомозиготним за цим локусом.

За результатами реконструкції генотипу сорту Сєвєрний була зроблена спроба проаналізувати його походження.

За доступною інформацією $[2,11]$ сорт Сєвєрний був отриманий у 1936 р. в результаті гібридизації Сєянєц Маллєнгра х Виноград амурський (V. amurensis Ruprecht).

В літературних джерелах нами були виявлені алельні характеристики лише прабатьківського для сорту Сєвєрний та батьківського для сорту Сєянєц Маллєнгра - сорту Малєнгр ранній, який показав три однакових алелів із сортом Сєвєрний у восьми проаналізованих локусах (дані не наведені). Враховуючи непрямі батьківські стосунки, можливість високої гетерозиготності сорту Сєянєц Маллєнгра та невелику кількість досліджених локусів такий результат може бути цілком ймовірним.

За даними [5] вид Виноград амурський є досить поліморфним і ряд його представників активно використовувався в селекційних процесах на початку XX ст.

Так, дослідники на чолі з Riaz S. [9] у 2013 р. проаналізували за допомогою мікросателітних маркерів вибірку з 380 сортів та виявили сім різних генотипів V. amurensis, жоден з яких не показав необхідних 50 \% однакових алелів із сортом Сєвєрний.

Таким чином наразі не можливо достеменно встановити походження сорту Сєвєрний.

Білоягідний винний сорт Одеський стійкий $є$ міжвидовим гібридом із високою стійкістю до низьких температур та мілдью $[2,11]$. Європейський каталог сортів Вітіс надає інформацію щодо існування трьох сортів-нащадків (Іллічівський ранній, Овідіопольський та Рубін таїровський) і входження сорту Одеський стійкий до колекцій наукових установ Болгарії та Молдови. 
ISSN 2077-1746. Вісник ОНУ. Біологія. 2015. Т. 20, вип. 1(36)

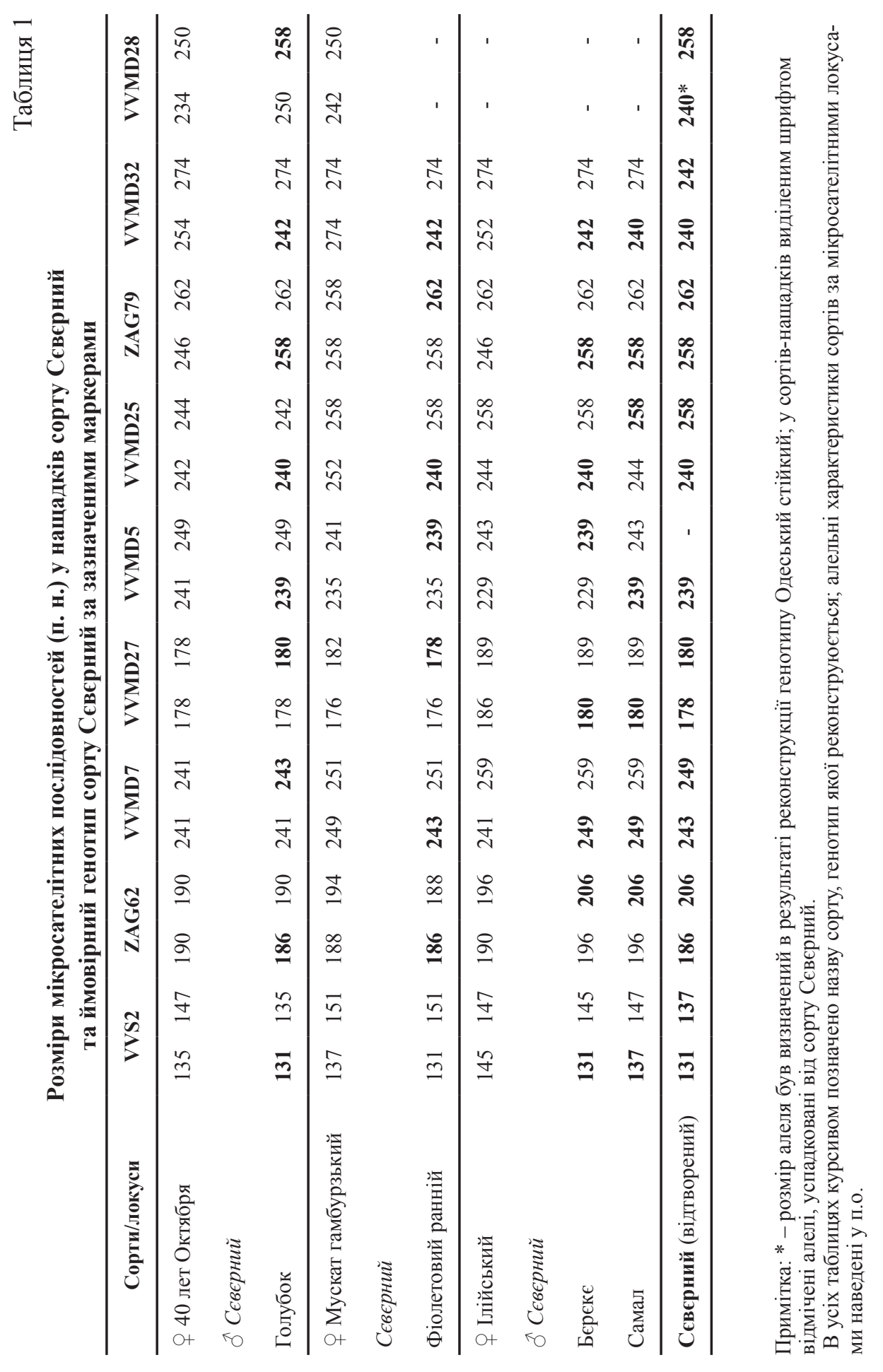


ISSN 2077-1746. Вісник ОНУ. Біологія. 2015. Т. 20, вип. 1(36)

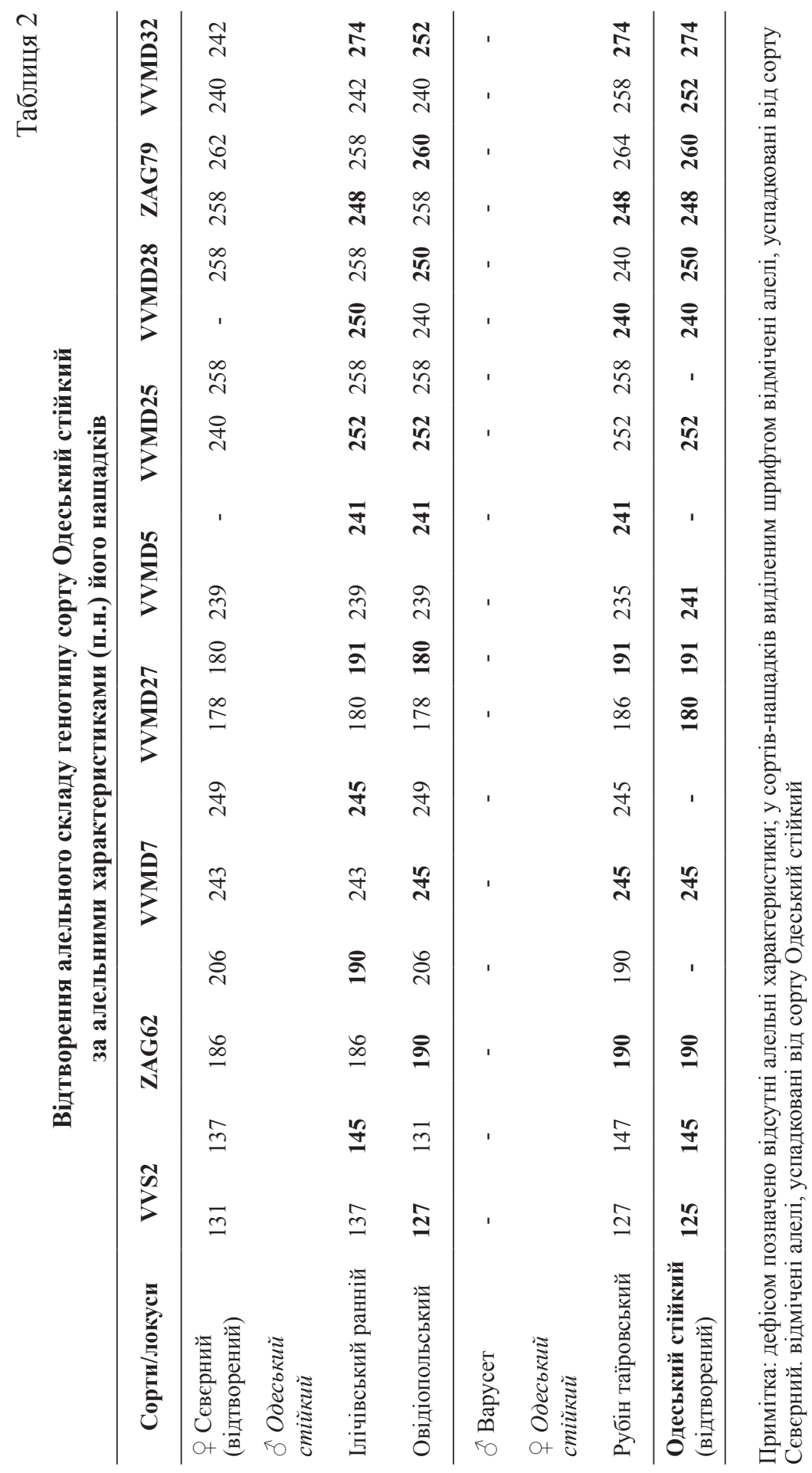


ISSN 2077-1746. Вісник ОНУ. Біологія. 2015. Т. 20, вип. 1(36)

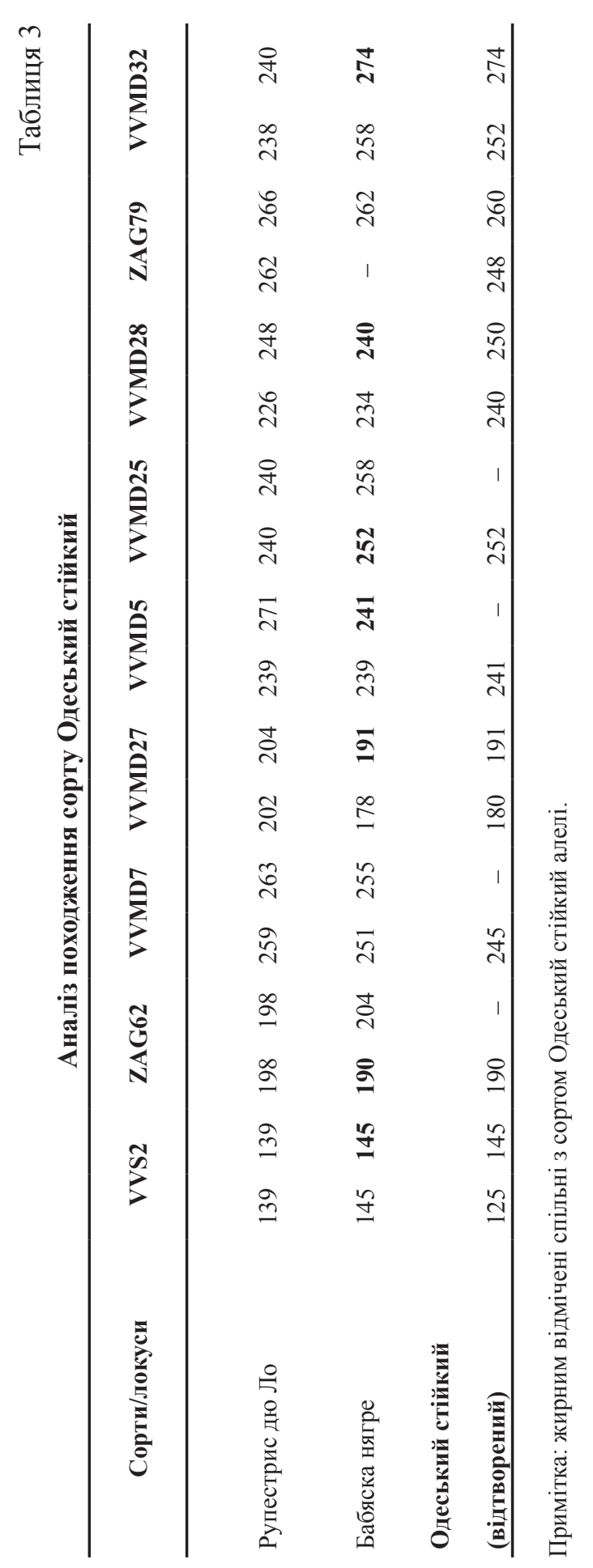


При реконструюванні генотипу Одеський стійкий було визначено повний алельний склад лише п'яти локусів (табл. 2) через невелику кількість його сортів-нащадків, обмежену інформативність генотипу сорту Сєвєрний та відсутність мікросателітних профілів сорту Варусет.

За локусами ZAG62, VVMD7 та VVMD5 всі нащадки Одеського стійкого успадкували лише алелі 190 п. о., 245 п. о. та 241 п. о., відповідно. Можливо дані локуси є гомозиготними.

Рубін таїровський у локусі VVMD28 показав два алеля 240 п. о., тобто один 3 них був отриманий від сорту Одеський стійкий. Генотип Овідіопольського, що є нащадком Одеського стійкого, виявив алелі розмірами 240 та 250 п. о. Алель 250 п. о. був успадкований від сорту Одеський стійкий, відповідно, алель 240 п. о. - від сорту Сєвєрний.

В селекційних записах, а також деяких відкритих інформаційних джерелах $[2,11]$ вказано походження сорту Одеський стійкий від гібридизаційної пари Бабяска нягре - Рупестрис дю Ло.

Сорт Одеський стійкий виявив однакові алелі в усіх 7 досліджених локусах (табл. 3) із сортом Бабяска нягре та жодного - із генотипом Рупестріс дю Ло. Таким чином, можна говорити про відсутність родинних зв'язків між сортами Одеський стійкий та Рупестрис дю Ло.

Столовий сорт раннього строку дозрівання Декоративний був виведений у колишньому СРСР та активно залучався до гібридизаційного процесу в ННЦ «IBiB ім. B. С. Таїрова». За інформацією Vivc сорт не $\epsilon$ дуже поширеним та наразі входить до колекцій сортів наукових установ України, США та Росії. В якості нащадків показні лише сорти Ланка та Смєна. Проте в колекції сортів винограду ННЦ «IBiB ім. В. С. Таїрова» існують ще два сорти-нащадки Декоративного - це Огоньок таїровський та Етюд. Всі чотири сорти походять від однієї гібридизаційної пари - Декоративний х Датьє де Сен Вальє.

Мікросателітний аналіз сортів-нащадків та залучення алельних характеристик Датьє де Сен Вальє, надали можливість більш повного, у порівнянні з попереднім сортом, відтворення генотипу сорту Декоративний (табл. 4).

Так для восьми локусів (VVS2, ZAG62, VVMD5, VVMD7, VVMD27, VVMD28, ZAG79, VVMD32) були відтворені повні генотипи, в локусі VVMD25 був визначений один алель (табл. 4).

Вважається $[2,11]$, що сорт Декоративний є результатом схрещування сортів Сапєраві та Сєвєрний.

Реконструювання генотипу сорту Сєвєрний та залучення алельних характеристик сорту Сапєраві надало можливість проаналізувати ймовірне походження сорту Декоративний (табл. 5).

Порівняння алельних характеристик сортів Декоративний та Сєвєрний показало наявність однакових алелів у восьми 3 дев'яти досліджених локусів. У локусі VVMD28 реконструйовані генотипи Декоративного (242:250) та Северного (240:258) показали розбіжність в одному алелі у 2 п.о, яка може бути 

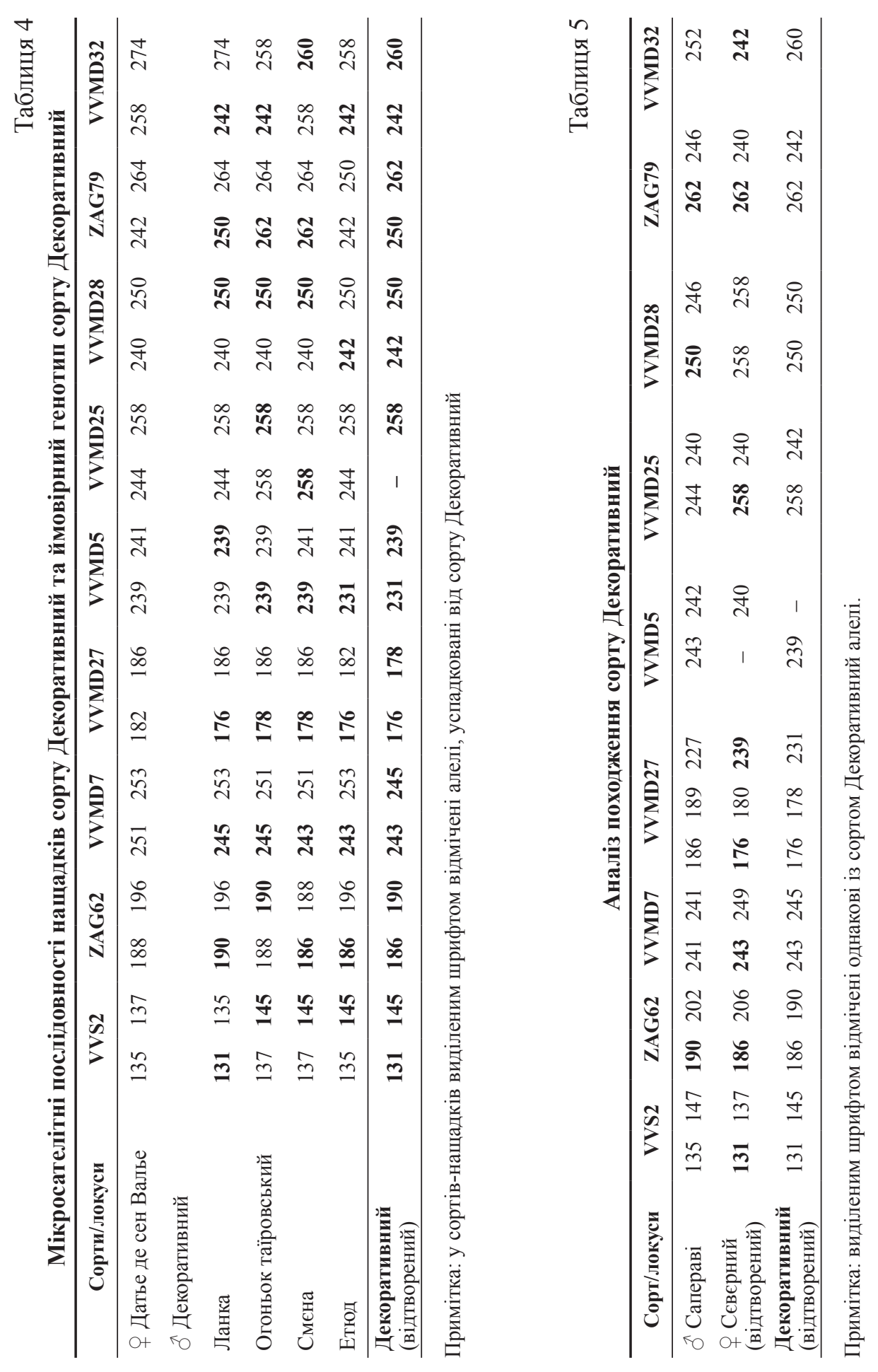
результатом точкової мутації сорту Декоративний або сорту Етюд, за яким відтворювався генотип Декоративного. Слід зауважити, що визначення алельних розмірів 3 використанням капілярного електрофорезу мало три повторності, результати яких показали генотип сорту Етюд у локусі VVMD28 - 242:250 п.о.

Сорт Сапєраві виявив відсутність однакових алелів у шести з дев'яти локусів, що дозволяє достеменно стверджувати про відсутність стосунків «нащадокбатьківський сорт» у сортів Сєвєрний та Сапєраві.

\section{Висновки}

1. Отримано алельні характеристики дев'яти мікросателітних локусів шести сортів винограду - Мускат гамбурзький, Овідіопольський, Огоньок таїровський, Смєна, Ланка та Етюд.

2. Відтворено генотипи за мікросателітними локусами трьох важливих батьківських сортів винограду - Сєвєрний, Одеський стійкий та Декоративний.

3. Встановлено походження сорту Одеський стійкий від сорту Бабяска нягре; сорт Рупестрис дю Ло відхилений в якості батьківського сорту.

4. Порівняння реконструйованого генотипу сорту Декоративний із генотипами ймовірних батьків підтвердило батьківство лише сорту Сєвєрний.

В подальшому отримані генотипи сортів Сєвєрний, Одеський стійкий та Декоративний будуть використані для дослідження ідентичності за походженням інших їх сортів-нащадків та планування гібридизаційних схем 3 метою підвищення ефективності селекційного процесу.

\section{Список використаної літератури}

1. Аубакирова К. П. Использование универсальных флуоресцентно-меченых праймеров в генотипировании казахстанских сортов винограда по микросателлитным маркерам [Електронний ресурс] / К. П. Аубакирова, М. Е. Омашева, Н. А. Рябушкина [и др.] // Биотехнология. Теория и практика. - 2013. - № 2. Режим доступу: http://www.biotechlink.org/Articles.aspx?articleID=133

2. Виноград [Електронний ресурс]. - Режим доступу: http:/vinograd.info/

3. Мікросателітний аналіз походження сортів та форм винограду селекції ННЦ «ІВіВ ім. В. С. Таїрова»/ О. М. Карастан, Н. А. Мулюкіна, Г. В. Плачинда [та ін.] // Виноградарство і виноробство: міжвідомчий тематичний науковий збірник. - Одеса: ННЦ «ІВіВ ім. В. Є. Таїрова», 2014. - Вип. 51. - С. $139-144$.

4. Карастан О. М. Происхождение некоторых форм винограда селекции ННЦ «ИВиВ им. В. Е. Таирова»/ О. М. Карастан, Н. А. Мулюкина, Е. С. Папина [и др.] // Агротехнологии XXI века: концепции устойчивого развития: материалы международной конференции, посвященной 100-летию кафедры ботаники, защиты растений, биохимии и микробиологии (Воронеж, 17-18 апреля 2014 г.): тезисы докл. Воронеж, 2014. - С. 341-346

5. Смирнов К. В. Виноградарство / К. В. Смирнов, Т. И. Калмыкова, Г. С. Морозова; под ред. К. В. Смирнова. - М.: Агропромиздат, 1987. - 367 с.

6. Large-scale parentage analysis in an extended set of grapevine cultivars (Vitis vinifera L.) / T. Lacombe, J. M. Boursiquot, V. Laucou [et al.] // Theor. Appl. Genet. - 2012. - Vol. 126. - № 2. - P. 401-414.

7. Sefc K. M. Microsatellite markers for grapevine: A state of the art/K. M. Sefc, F. Lefort, S. Grando; K. A. Roubelakis-Angelakis editor / Amsterdam: Kluwer Publishers, 2001. - P. 433-463.

8. High throughput analysis of grape genetic diversity as a tool for germplasm collection management / V. Laucou, T. Lacombe, F. Dechesne [et al.] // Theor. Appl. Genet. - 2011. - Vol. 122. - № 6. - P. 1233-1245.

9. Identification of mildew resistance in wild and cultivated Central Asian grape germplasm / S. Riaz, J. M. Boursiquot, G. S. Dangl [et al.] // BMC Plant Biol. - 2013. - Vol. 13. - P. 149. 
10. The SSR-based molecular profile of 1005 grapevine (Vitis vinifera L.) accessions uncovers new synonymy and parentages, and reveals a large admixture amongst varieties of different geographic origin / G. Cipriani, A. Spadotto, I. Jurman, [et al.] // Theor. Appl. Genet. - 2010. - Vol. 121. - № 8. - P. 1569-1585.

11. Vitis International Variety Catalogue [Електронний ресурс]. - Режим доступу: http://www.vivc.de/

12. Microsatellite database of grapevine (Vitis vinifera L.) cultivars used for wine production in Portugal / M. Veloso, M. C. Almandanim, M. Baleiras-Couto [et al.] // Ciência Téc. Vitiv. - 2010. - Vol. 25. - № 2. - P. 53-61.

Статьтя надійшла до редакції 20.12.2014

\title{
О. М. Карастан
}

Национальный научный центр «Институт виноградарства и виноделия им. В. Е. Таирова»

ул. 40-летия Победы, 27, пгт. Таирово, Овидиопольский р-н, Одесская обл., 65496, Украина, e-mail: olga.karastan@gmail.com

\section{РЕКОНСТРУКЦИЯ ГЕНОТИПОВ И АНАЛИЗ ПРОИСХОЖДЕНИЯ СОРТОВ ВИНОГРАДА СЕВЕРНЫЙ, ОДЕССКИЙ УСТОЙЧИВЫЙ И ДЕКОРАТИВНЫЙ}

\begin{abstract}
Резюме
Получены аллельные профили девяти микросателлитных локусов (VVS2, VVMD5, VVMD7, VVMD25, VVMD27, VVMD28, VVMD32, ZAG79 и ZAG62) шести сортов винограда селекции ННЦ «ИВиВ им. В. Е. Таирова». Анализ микросателлитных характеристик сортов-потомков был использован для реконструкции генотипов сортов родительских Северный, Одесский устойчивый и Декоративный. Подтверждены отношения «потомок-родительский сорт» для сортов Одесский устойчивый-Бабяска нягрэ и Декоративный-Северный.

Ключевые слова: генотип, аллель, микросателлитный анализ, виноград, Vitis vinifera $L$.
\end{abstract}

\section{O. M. Karastan}

National Scientific Center Tairov «Institute of Viticulture and Winemaking»

40 let Pobeda str., 27, village Tairovo, Ovidiopolskiy district, Odessa region 65496,

Ukraine, e-mail: olga.karastan@gmail.com

\section{GENOTYPES RECONSTRUCTION AND PEDIGREE ANALYSIS OF GRAPE VARIETIES SEVERNY, ODESSKIY USTOYCHIVIY AND DEKORATIVNIY}

\begin{abstract}
Summary
Allelic profiles of nine microsatellite loci (VVS2, VVMD5, VVMD7, VVMD25, VVMD27, VVMD28, VVMD32, ZAG79, ZAG62) for six grape varieties bred at National Scientific Center "Tairov Institute of Viticulture and Winemaking" were obtained. Microsatellite analysis offspring varieties allelic characteristics were used for the reconstruction of genotypes varieties Severnyi, Odesskiy ustoychiviy and Decorativniy. "Descendant-parent" relationships were confirmed for cultivars Odeskiy ustoychiviy-Babeasca neagra and Decorativniy-Severniy.

Key words: genotype, allele, microsatellite analysis, grapewine, Vitis vinifera $L$.
\end{abstract}

